\title{
MENINGKATKAN KUALITAS PEMBELAJARAN DAN PENGAJARAN MELALUI MODEL KURIKULUM YANG EFISIEN
}

\author{
James Jimry Wawaan Anak John Yugis* \\ Malaysia Evangelical Theological Seminary, Miri, Malaysia \\ *johnjjw24@gmail.com
}

\begin{abstract}
Learning is a relatively permanent change in behavior or potential behavior as a result of experience. Learning is the interaction between stimulus and response. These issues are very useful when reviewed as follows: What is the meaning of Learning and Teaching? What are the methods for improving the Quality of Learning and Teaching? How to Improve the Quality of Learning and Teaching through an Efficient Curriculum Model? The answers to the problems are: (1) the notion of learning and teaching is a different concept even though it is a process of change in the structure of learning, which involves teachers, students and educational infrastructure. (2) methods for improving the quality of learning and quality improvement are: learning communication and quality improvement, collaboration, and developing various forms of learning. (3) improving the quality of learning and building through efficient curriculum models are: the Ralp W. Tyler curriculum model, the Hilda Taba curriculum model, the Peter Oliva curriculum model, or the Muray Print curriculum model.
\end{abstract}

\section{Keywords: Learning and Teaching, Quality, and Curriculum}

\begin{abstract}
Abstrak: Belajar merupakan perubahan yang relatif permanen dalam perilaku atau potensi perilaku sebagai hasil dari pengalaman. Belajar adalah interaksi antara stimulus dan respon. Persoalan-persoalan tersebut sangatlah berguna bila dikaji kembali sebagai berikut: Apakah pengertian Pembelajaran dan Pengajaran? Bagaimanakah kaedah-kaedah untuk meningkatkan Kualitas Pembelajaran dan Pengajaran? Bagaimanakah Meningkatkan Kualitas Pembelajaran dan Pengajaran melalui Model Kurikulum yang Efisien? Jawaban persoalan adalah: (1) pengertian Pembelajaran dan Pengajaran merupakan suatu konsep yang berbeda meski menjadi proses perubahan dalam struktur belajar, yang melibatkan pengajar, pelajar, dan prasarana pendidikan. (2) kaedah-kaedah untuk meningkatkan kualitas pembelajaran dan pengajaran adalah dengan meningkatkan kualitas adalah: komunikasi pembelajaran dan pengajaran, kolaborasi, dan mengembangkan bentuk pembelajaran yang bervariasi. (3) meningkatkan kualitas pembelajaran dan pengajaran melalui model-model kurikulum yang efisien adalah: model kurikulum Ralp W.Tyler, model kurikulum Hilda Taba, model kurikulum Peter Oliva, atau model kurikulum Muray Print.
\end{abstract}

Kata Kunci: Pembelajaran Dan Pengajaran, Kualitas, dan Kurikulum 


\section{PENDAHULUAN}

Dunia kini terlihat semakin maju dan berkembang pesat dengan kemudahan dan infrasturktur yang nyaman dan canggih serta efisien. Rangkaian internet yang berkelajuan tinggi memudahkan manusia berkomunikasi dan mendapatkan informasi apa yang selalu diperlukannya.

Jogiyanto mengatakan bahwa informasi adalah hasil dari pengolahan data dalam suatu bentuk yang lebih berguna dan lebih berarti bagi penerimanya yang menggambarkan suatu kejadian - kejadian (event) yang nyata (fact) yang digunakan untuk pengambilan keputusan. ${ }^{1}$ Seiring dengan masa internet ini, tidak ketinggalan juga dalam hal pembelajaran dan pengajaran menunjukkan beberapa kemajuan seperti pembelajaran digunakan secara atas talian, sumber sumber pengajaran dan rujukan mudah didapati melalui digital dan e-Book. Dengan demikian life style belajar pun beradaptasi dengan perkembangan teknologi yang semakin hari semakin tinggi. Belajar merupakan perubahan yang relatif permanen dalam perilaku atau potensi perilaku sebagai hasil dari pengalaman. Belajar adalah interaksi antara stimulus dan respon. ${ }^{2}$

Pembelajaran adalah proses, cara, perbuatan menjadikan orang atau makhluk hidup belajar. Definisi sebelumnya menyatakan bahwa seorang manusia dapat melihat dalam perubahan yang terjadi, tetapi tidak pembelajaran itu sendiri. ${ }^{3}$ Konsep tersebut adalah teoretis, dan dengan demikian tidak secara langsung dapat diamati: "manusia telah melihat individu mengalami pembelajaran,

individu berperilaku dalam cara tertentu sebagai hasil dari pembelajaran, dan beberapa dari dirinya telah "belajar" dalam suatu tahap dalam hidupnya. Pembelajaran telah terjadi ketika seorang individu berperilaku, bereaksi, dan merespon sebagai hasil dari pengalaman

\footnotetext{
${ }^{1}$ Jogiyanto H.M, Analisis dan Disain Sistem Informasi (Yogjakarta: Andi, 1999), 692.

${ }^{2}$ Robert E. Slavin, Educational Psychology: Theory and Practice (New Jersey: Pearson Education, 2000), 143.

${ }^{3}$ Stephen P. Robbins, Perilaku Organisasi Buku 1 (Jakarta: Salemba Empat, 2007), 69-79.
}

14 | Vol. 2 No. 2 (Juli-Desember 2018) dengan satu cara yang berbeda dari caranya berperilaku sebelumnya". 4

Pentingnya keterlibatan langsung dalam belajar dikemukakan oleh John Dewey dengan "learning by doing"-nya. Belajar sebaiknya dialami melalui perbuatan langsung dan harus dilakukan oleh siswa secara aktif. Prinsip ini didasarkan pada asumsi bahwa para siswa dapat memperoleh lebih banyak pengalaman dengan cara keterlibatan secara aktif dan proporsional, dibandingkan dengan bila mereka hanya melihat materi (konsep). Modus Pengalaman belajar adalah sebagai berikut: seserang belajar $10 \%$ dari apa yang ia baca, 20\% dari apa yang ia dengar, 30\% dari apa yang ia lihat, 50\% dari apa yang ia lihat dan dengar, 70\% dari apa yang ia katakan, dan 90\% dari apa yang ia katakan dan lakukan. Hal ini menunjukkan bahwa jika guru mengajar dengan banyak ceramah, maka peserta didik akan mengingat hanya 20\% karena mereka hanya mendengarkan. Sebaliknya, jika guru meminta peserta didik untuk melakukan sesuatu dan melaporkannya, maka mereka akan mengingat sebanyak $90 \% .^{5}$

Pembelajaran dan pengajaran akan kurang berkesan jika adanya masalah kesukaran untuk menyampaikan pengajaran atau kesukaran penerimaan pengajaran yang disampaikan. Hal ini demikian karena dalam proses pembelajaran dan pengajaran melibatkan seorang pendidik dan seorang yang dididik. Setiap pendidik mempunyai tahap kemampuan dan kemahiran yang berbeda dan begitu juga dengan anak didik, mereka juga memiliki variasi perbedaan seperti: intelek, jasmani, rohani dan sosio ekonomi. Walaupun demikian, sarana dan konsep dalam pembelajaran dan pengajaran juga diketegahkan dalam menilai kualitas pembelajaran dan pengajaran. Hal ini bukan merujuk kepada pembelajaran dan pengajaran dalam institusi pendidikan umum atau teologi saja, malah pembelajaran dan pengajaran

\footnotetext{
${ }^{4}$ W. McGehee, "Are We Using All We Know About Training? Learning Theory and Training," Personnel Psychology, (Spring 1958), 2.

5"Belajar," Wikipedia bahasa Indonesia, ensiklopedia bebas, November 19, 2020, accessed November 24, 2020, https://id.wikipedia.org/w/index.php?title=Belajar\&oldi $\mathrm{d}=17623207$.
} 
dalam pelayanan gereja atau pelayanan pastoral juga diperhatikan, bagaimana caranya dapat membawa para jemaah untuk belajar dan mengetahui tentang Firman TUHAN lebih mendalami dan sistematik.

Persoalan-persoalan tersebut sangatlah berguna bila dikaji kembali sebagai berikut: Apakah pengertian Pembelajaran dan Pengajaran? Bagaimanakah kaedah-kaedah untuk meningkatkan Kualitas Pembelajaran dan Pengajaran? Bagaimanakah Meningkatkan Kualitas Pembelajaran dan Pengajaran melalui Model Kurikulum yang Efisien?

\section{PEMBAHASAN}

\section{Pengertian Pembelajaran dan Pengajaran}

Pembelajaran dan pengajaran merupakan suatu konsep yang berbeda meski menjadi proses perubahan dalam struktur belajar. Kata pembelajaran tidak hanya ada dalam konteks guru dengan peserta didik di kelas secara formal, akan tetapi juga meliputi kegiatan-kegiatan belajar peserta didik di luar kelas yang mungkin saja tidak dihadiri oleh guru secara fisik. Pembelajaran lebih menekankan pada kegiatan belajar peserta didik secara sunggh-sungguh yang melibatkan aspek intelektual, emosional, dan sosial, sedangkan pengajaran lebih cenderung pada kegiatan mengajar guru di kelas. Pengajaran lebih bersifat formal dan hanya ada di dalam konteks guru dengan peserta didik di kelas (sekolah). Pengajaran identik dengan sekolah, guru, dan anak didik. Pengajaran secara leksikal berari suatu proses memberikan ajaran (nasihat, petuah, petunjuk) kepada anak didik tentang pengalaman, pengetahuan, peristiwa yang dialami dan dilihatnya. ${ }^{6}$

Pengajaran menjelaskan tentang suatu tugasan dan aktivitas yang dilakukan bersama oleh sang pendidik dan anak didiknya serta dirancang oleh seorang guru secara sistematik dengan menggunakan kaedah dan teknik yang sesuai menghasilkan sebuah lingkungan untuk terjadinya proses belajar. Tetapi proses pembelajaran tidak boleh dipisahkan dengan

${ }^{6}$ Zainal Arifin, Evaluasi Pembelajaran. Teknik, Prinsip, dan Prosedur (Bandung: Remaja Rosdakarya, 2016), 20-22. proses pengajaran dalam membangun sebuah komunitas belajar dan mengajar yang baik. Pembelajaran dan pengajaran proses belajar menajar yang sudah dimulai di Taman Eden, di mana TUHAN memberikan nasihat dan ajaran kepada Adam dan Hawa tentang apa yang mereka perlu lakukan dan tidak boleh dilakukan. Bahkan, anak murid Yesus Kristus diajarkan oleh Yesus Kristus di bukit dalam Perjanjian Baru. Para murid diberikan pengajaran bagaimana kehidupan yang benar di hadapan TUHAN sebagai orang yang percaya. Jadi, proses pembelajaran dan pengajaran terus berjalan jika adanya pengajar dan pelajar dalam lingkungan belajar.

Pembelajaran dan pengajaran yang efektif dapat mendukung pelajar lebih kreatif karena dalam proses pengajaran berkaitan dengan pengembangan idea-idea dan memudahkan cara pembinaan ilmu dan mencungkil kreativitas di samping menggalakkan anak didik untuk belajar dengan memaksimumkan pencapaian yang cemerlang. ${ }^{7}$ Lebih lanjut, Noor Lela, dkk., mengatakan bahwa Manakala dimensi amalan pengajaran dan pembelajaran abad 21 yang terendah adalah adalah dimensi kemahiran kolaborasi. Dapatan menunjukkan bahawa amalan pengajaran dan pembelajaran abad 21 mendorong emosi pelajar dalam melaksanakan aktiviti pembelajaran dimana berada pada tahap min yang tinggi. Hasil kajian membuktikan amalan pengajaran dan pembelajaran abad 21 memberi impak yang positif kepada pembangunan pelajar. ${ }^{8}$

\section{Kriteria - Kriteria yang Mendukung Pembelajaran dan Pengajaran yang Efektif Kriteria yang mendukung pembelajaran dan pengajaran yang efektif selalu melibatkan dua pihak yang aktif, yaitu: seorang pendidik dan anak didik. Proses belajar itu menuju kepada hasil yang berkualitas. Kualitas adalah ukuran baik buruknya sesuatu, kadar, mutu, derajat (taraf) kepandaian atau kecakapan. Pembelajaran}

${ }^{7}$ Noor Lela, dkk., (2019), “Kepentingan Amalan Pengajaran dan Pembelajaran Abad 21 terhadap pembangunan pelajar", International Journal of Education, Psychology and Counseling, 4(28), 28-51. ${ }^{8}$ Ibid.

Excelsis Deo: Jurnal Teologi, Misiologi, dan Pendidikan | 15 
adalah suatu upaya untuk mengubah tingkah laku siswa ke arah yang lebih baik. Kualitas proses pembelajaran dapat dilihat dari aktivitas belajar dan pemahaman siswa berdasar kompetensi dasar dan indikator yang harus dicapai, serta kinerja guru yang mendukung proses pembelajaran. Kompetensi Dasar dan Indikator yang harus dicapai, serta kinerja guru yang mendukung proses pembelajaran.

Berkaitan hal tersebut, maka Trianto mengatakan bahwa sesuai dengan teori perkembangan kognitif bahwa sebagian besar kognitif anak ditentukan oleh manipulasi dan interaksi aktif anak dengan lingkungan maupun pengalaman-pengalaman fisik. Piaget menyatakan bahwa interaksi sosial dengan teman sebaya, khususnya berargumentasi dan berdiskusi membantu memperjelas pemikiran yang pada akhirnya memuat pikiran itu menjadi lebih logis. ${ }^{9}$ Menurut Piaget berpikir logis dimaknai dengan berpikir tentang berbagai hal termasuk hal yang rumit, tetapi dengan syarat bahwa hal-hal tersebut disajikan secara konkret (disajikan dalam wujud yang bisa ditangkap dengan panca indera). ${ }^{10}$ Dengan demikian, maka kualitas interaksi antara pendidik (guru) dan anak (siswa) merupakan penentu lahirlah kualitas. Karena sangat diperlukan proses pembelajaran dan pengajaran yang seefektif mungkin antara guru dan siswa.

\section{Pengajar}

Pengajar merupakan orang yang mengajar. ${ }^{11}$ Pengajar ini boleh dikaitkan dengan guru, pensyarah, pastor atau fasilitator. Individu ini dianggap penting dalam Pembelajaran dan Pengajaran karena mereka inilah yang menyampaikan dan mengajar setiap anak didik. Hal ini demikian karena jika pengajarnya mengajarkan hal yang sesat, maka akan lahir seorang anak didik yang sesat, seperti kata yang mengatakan "orang buta memimpin orang

${ }^{9}$ Trianto, Mendesain Model Pembelajaran Inovatif-Progresif (Jakarta: Kencana Prenada Media Group, 2011), 29.

${ }^{10}$ Saminanto, Ayo Praktik PTK (Penelitian Tindakan Kelas) (Semarang: Rasail Media Group, 2010), 19.

${ }^{11}$ www.makna.online.com

16 | Vol. 2 No. 2 (Juli-Desember 2018) yang buta berjalan". Apatah lagi, jika berkaitan dengan hal kerohanian. Melahirkan hamba TUHAN atau jemaah yang produktif perlu dimuatkan dengan pengajaran yang lengkap dan dipahami dengan benar. Justru, pengajar perlu dilihat sebagai hal vital untuk memiliki kriteria yang sesuai sebagai berikut:

Pertama, seorang pengajar harus merupakan seorang individu yang berlayakan dalam bidang akademik. Ini bermaksud seorang pengajar memiliki lulusan akademik yang setaraf dan sepadan untuk tahap pendidikan yang diajarkan seperti seorang yang mengajar pada peringkat diploma atau degree harus memiliki lulusan program master $^{12}$. Kedua, seorang pengajar memiliki jasmani dan rohani yang sihat. Hal ini dijelaskan bahawa seorang pengajar perlu memiliki tubuh jasmani yang bebas dari penyakit dan rasional atau emosi yang stabil. Ketiga, seorang pengajar perlu mempunyai kompetensi seperti kompetensi pedagogic, kompetensi kepribadian, kompetensi sosial dan kompetensi professional ${ }^{13}$. Wajibnya seorang pengajar memiliki kompetensi untuk menyakinkan para pelajar dalam menerima ajaran. Keempat, pengajaran itu bukan hanya bersifat teori, melainkan sebuah penunjang dalam kehidupan seharian yang bermutu dan berkualiti. Dalam hal ini, seorang pengajar itu berarti sudah sesungguhnya menguasai setiap bahan pelajaran yang akan diajarkan, bahkan bukan sahaja menguasai bahan pelajaran secara kognitif, malah bahan pelajaran sudah menjadi sebuah gaya hidup atau amalan hidupnya seharian karena quantum learning merumuskan bahwa peratusan untuk seorang pelajar memahami pelajaran melalui mendengar dan melihat ialah 50 persen.

Kelima, pengajar perlu memiliki visi untuk mengajar. Hal ini demikian karena seorang pengajar bertindak sebagai penunjuk atau pemimpin dalam pendidikan. Mehmet Muhat Ildan mengatakan, "A leader without vision is just a letter without a stamp; it can never reach his destination". ${ }^{14}$

\footnotetext{
${ }^{12}$ Harianto GP, Akselerasi Peningkatan Mutu Dosen. Monograf (Jakarta: BMPTKKI, 2019), 5.

${ }^{13}$ Harianto GP, Akselerasi Peningkatan Mutu Dosen, 6

${ }^{14} \mathrm{https} / / / \mathrm{www} . q u o t e s . n e t / q u o t e / 22671$.
} 
Ini menjelaskan bahwa jika seorang pengajar tidak mempunyai visi dalam mengajar, dia tidak akan mengetahui sebagaimana dia harus mengajar dan tujuan dia mengajar muridnya. Apatah lagi, untuk memimpin anak didik untuk menguasai pengajaran.

Keenam, pengajar mempunyai sikap untuk mengenal pribadi pelajar atau anak didik harus ada dalam diri seorang pengajar bukan saja mampu untuk mengajarkan bahan ajaran. Sebagaimana pelayanan Kristus bersama para murid-Nya, Yesus terlebih dahulu memahami latar belakang setiap anak murid-Nya, bahkan budaya dan tradisi setiap tempat yang Dia akan kunjungi sebelum menyampaikan pengajaran kepada mereka. Mengenali setiap pelajar ini bertujuan untuk memudahkan pengajar menerapkan pengajaran dan bahan belajar kepada

pelajarnya. Mana mungkin, pelajar yang sudah mahir memasak mahu disuruh untuk belajar memasak atau pelajar yang buta warna disuruh untuk mewarna.

\section{Pelajar}

Pelajar merujuk kepada siapa saja yang sedang atau dalam keadaan belajar. ${ }^{15}$ Manusia dapat mengerti bahwa pelajar itu boleh terdiri dari adalah murid sekolah rendah atau menengah, pelajar Kolej atau Universiti, guru - guru yang melanjutkan pendidikan, jemaah yang mendengar khotbah dalam gereja atau invididu yang sedang menghadiri ceramah atau seminar. Pelajar juga memainkan peranan dalam proses belajar mengajar bergerak efektif dan efisien. Hal ini demikian karena sebuah pengajaran dapat dianggap berjaya disampaikan atau berkesan tergantung jika adanya hasil perubahan dan perkembangan kognitif, afektik dan psikomotorik terhadap pendengar didikan.

Kesan didikan terlihat daripada perkembangan pelajar dari masa ke masa. Maka dengan demikian, pelajar termasuk dalam elemen pergerakan pembelajaran dan

15"Peserta didik," Wikipedia bahasa Indonesia, ensiklopedia bebas, August 19, 2020, accessed November 24, 2020, https://id.wikipedia.org/w/index.php?title=Peserta_didi k\&oldid=17316371. pengajaran.

Sebuah pepatah yang mengatakan, "sebelum kita dapat memahami pelajaran, kita harus terlebih dahulu mencintai pelajaran tersebut". Hal ini menjelaskan: (1) seorang pelajar harus siap terbuka untuk menerima ajaran dan pengajaran yang disampaikan oleh pengajarnya dengan memotivasikan diri tujuan ilmu dipelajari dan kegunaan ilmu yang diperolehi pada masa kelak. ${ }^{16}$ (2) seorang pelajar harus memiliki persediaan dari segi mental, fizikal dan rohani untuk belajar. Persediaan yang baik dapat mendorong pelajar untuk memberi tumpuan yang sepenuhnya terhadap pelajaran yang disampaikan. ${ }^{17}$

\section{Kemudahan}

Kemudahan yang sesuai dan lengkap bukan saja membantu pergerakan Pembelajaran dan Pengajaran, bahkan mendukung para pelajar untuk bersemangat dan aktif dalam belajar dan memudahkan para pengajar dapat menyampaikan isi kandungan pelajaran kepada anak didiknya. Kemudahan bisa berupa:

Pertama, "bahan ajar". Bahan Ajar sebagai medium pengajaran merupakan segala sesuatu yang menjadi inti kurikulum yang harus dikuasai oleh mahasiswa (siswa). Bahan ajar ini boleh diklasifikasikan sebagai buku pelajaran, model, alat peraga atau handout yang berfungsi untuk memberikan informasi tambahan selain daripada penyampaian pengajaran secara verbal.

Kedua, prasarana merujuk kepada keseluruhan kemudahan perlu bagi pembangunan dan kemajuan. ${ }^{18}$ Prasarana institusi perlu diambil dalam meningkatkan kualitas pendidikan. Mungkin ada segelintir menolak pandangan ini kerana ada yang berpendapat bahwa keadaan sekitar tidak akan mempengaruhi pelajar jika mereka memiliki semangat dan moral yang tinggi dalam belajar. Namun prasarana mendukung dalam kelancaran pembelajaran seperti adanya kemudahan teknologi, kemudahan alat kemahiran dan sebagainya. Dengan adanya prasarana yang lengkap, dapat

\footnotetext{
${ }^{16}$ www.bobezani.tripod.com

${ }^{17}$ Ibid.

${ }^{18}$ www.prpm.dbp.gov.my.com
}

Excelsis Deo: Jurnal Teologi, Misiologi, dan Pendidikan | 17 
mengembangkan pengetahuan pelajar secara praktikal bagi setiap pelajaran yang diajarkan. Sebagai contoh, pelajaran kemahiran tidak akan dapat berkembang jika diajarkan secara teori tanpa adanya kemudahan untuk pelajar dapat mempraktikkan teori yang dipelajari. Kelengkapan prasarana dalam setiap institusi pendidikan menjadi pemangkin kepada pelajar untuk lebih berdisiplin dan berprestasi yang baik dalam proses Pembelajaran dan Pengajaran. ${ }^{19}$ Kemudahan pendidikan di institusi diklasfikasikan seperti bilik darjah, makmal sains, pejabat, perpustakaan dan sebagainya. Manakala, di gereja merujuk kepada kemudahan seperti bilik Sekolah Minggu, LCD, bilik pertemuan atau ruangan gereja dan sebagainya. Kemudahan ini harus dipelihara dengan baik, disediakan dengan sepenuhnya dan ditetapkan dengan baik karena adalah sangat mempengaruhi perkembangan anak didik sepanjang pembelajaran dan pengajaran disajikan bagi mereka. ${ }^{20}$

Dari uraian tersebut dapat disimpulkan bahwa pembelajaran dan pengajaran merupakan suatu konsep yang berbeda meski menjadi proses perubahan dalam struktur belajar, yang melibatkan pengajar, pelajar, dan prasarana pendidikan.

\section{Kaedah-kaedah untuk Meningkatkan Kualitas Pembelajaran dan Pengajaran}

Sebuah institusi atau gereja mungkin akan menghadapi kesulitan dalam membawa pelajar atau jemaat untuk memahami pelajaran yang disampaikan. Sebagai contoh, pelajaran disampaikan selama sebulan, tetapi tiada perubahan yang ketara dapat ditunjukkan oleh pendengar. Dalam hal ini, menuding jari kepada pendengar dan menganggap mereka lembam atau degil sehingga tidak menerima ajaran yang diberikan adalah perkara yang harus dielakkan karena setiap manusia diciptakan oleh TUHAN pada dasarnya sangat baik. Jadi, hal yang mengakibatkan kecacatan dalam

${ }^{19}$ Nuzaruan Bin Razali, Tahap Prasarana Pendidikan Persekitaran Pembelajaran di Sekolah Menengah Daerah Kota Tinggi (Malaysia: Fakulti Pendidikan Universiti Teknologi Malaysia, 2013). ${ }^{20}$ Ibid.

18 | Vol. 2 No. 2 (Juli-Desember 2018)
Pembelajaran dan Pengajaran. Albert Einstein mengatakan, "Everybody is genius. But if you judge a fish by its ability to climb a tree, it will live its whole life believing that is stupid". Einstein menjelaskan bahwa kehebatan seseorang pelajar itu tergantung bagaimana proses Pembelajaran dan Pengajaran yang diberikan kepadanya. Hal ini tegas menjelaskan bahwa kaedah atau sistem Pembelajaran dan Pengajaran perlu diketengahkan untuk menjamin dan mendukung setiap pelajar dan pengajar dapat menjalankan proses belajar mengajar dalam arah visi dan misi pendidikan sebuah institusi atau gereja.

\section{Komunikasi Pembelajaran dan Pengajaran Komunikasi dalam proses} Pembelajaran dan Pengajaran amat berguna karena komunikasi yang berkesan boleh mewujudkan motivasi dan kecenderungan pelajar (anak didik) aktif untuk belajar. Kurang mahir dalam komunikasi melahirkan suasana Pembelajaran dan Pengajaran yang tidak kondusif dan produktif. ${ }^{21}$ Komunikasi dipengaruhi oleh interpretasi masing-masing individu tentang arti kata-kata dan tingkahlaku pengajar dan siswa. Komunikasi dapat berjalan dengan benar jika bahan ajar diinterpretasikan dengan cara yang sama oleh pengajar pemberi pesan dan siswa penerima komunikasi. ${ }^{22}$

Kelebihan komunikasi dan Pembelajaran dan Pengajaran adalah untuk mewujudkan sebuah persekitaran Pembelajaran dan Pengajaran yang aman dan harmonis, menolong pengajar memotivasikan murid-muridnya supaya berminat dalam belajar dan mewujudkan hubungan mesra antara pengajar dan pelajar agar proses Pembelajaran dan Pengajaran lebih menyeronokkan sebagai berikut: ${ }^{23}$

Pertama, Pembelajaran dan Pengajaran bentuk sehala. Pengajaran bentuk ini sering digunakan dalam mana - mana institusi mahupun dalam gereja ketika ibadah ahad. Pembelajaran dan Pengajaran bentuk sehala ini

\footnotetext{
${ }^{21}$ www.academia.edu.com

${ }^{22}$ Harianto GP, Komunikasi dalam Pemberitaan Injil (Yogjakarta: Andi, 2012), 11. ${ }^{23}$ Ibid.
} 
merupakan cara interaksi yang berpusat kepada guru atau ditentukan oleh guru kelas sahaja dan selalu adalah bersifat informasi seperti: cara bercerita, syarahan atau demontrasi. 24 Selalunya cara ini membosankan kalangan pelajar dan pendengar ajaran kerana cara ini tidak menggalakkan interaksi daripada sang pendengar atau dimengertikan sebagai pengajaran pasif. Namun kaedah untuk meningkatkan keberhasilan cara ini adalah dengan mempelbagaikan cara penyampaian seperti menggunakan: alat peraga, buku teks, slide pengajaran dan simulasi pergerakan. Hal ini karena menggalakkan pelajar atau jemaah untuk memahami pelajaran secara mendengar tidak berkesan untuk memberikan impak pengetahuan kepada mereka. Quantum learning menjelaskan bahwa peratusan pendengar belajar dari mendengar hanya 20 peratus saja. Namun, jika pelajar itu menerima ajaran dengan melihat dan mendengar, maka peratusannya untuk menerima ajaran adalah $30-50$ peratus.

Kedua, Pembelajaran dan Pengajaran bentuk dua hala. Dalam Pembelajaran dan Pengajaran berbentuk dua hala atau multi ini, seorang pengajar itu akan menggunakan cara interaksi yang bersifat perbincangan, di mana corak Pembelajaran dan Pengajaran lebih bersifat aktif dan melibatkan semua pelajar untuk ikut serta untuk berinteraksi. ${ }^{25}$ Pembelajaran dan Pengajaran dua hala merupakan proses pembelajaran antara guru dan murid atau mentor dan mentee. ${ }^{26}$ Lazimnya, cara ini digunakan untuk: (1) memupuk minat pelajar untuk berpikir secara kreatif dan kritis, dan (2) mendidik moral pelajar untuk mengamati pemikiran orang lain. Antara aktiviti yang dilakukan seperti perbincangan atau pembentangan topik dalam kumpulan dan sesi soal dan jawab atau forum.

Cara Pembelajaran dan Pengajaran dua hala ini mewujudkan suasana pembelajaran yang bersifat aktif, perhubungan kerjasama dapat terlihat, dan dipupuk dalam diri seorang pelajar. ${ }^{27}$

\footnotetext{
${ }^{24}$ Www.cikguazni87.blogspot.com

${ }^{25}$ Ibid.

${ }^{26}$ www.iqteach.com

${ }^{27}$ Ibid.
}

Komunikasi bentuk dua hala ini perlu diterapkan dalam pelayanan gereja seperti dalam kebaktian Ibadah Raya atau pertemuan kolompok sel dan anak muda. Hal ini demikian karena terlihat komunikasi begini mampu menarik fokus dan perhatian pendengar dalam penyampaian inti khotbah atau pengajaran Alkitab.

\section{Rangkaian yang Meluas}

Kolaboratif bermaksud kerjasama yang erat di antara dua pihak atau lebih yang merujuk kepada kerjasama ke arah melaksanakan sebuah aktviti kebaikan. ${ }^{28}$ Kolaboratif ini bertujuan untuk menghilangkan persaingan dan sifat perseorangan dalam kerjasama ${ }^{29}$ atau cara kerja teamwork. Cara ini dilaksanakan dengan semua anggota kelompok mencapai tujuan dengan bersama-sama ${ }^{30}$ yang walaupun melibatkan pemikir-pemikir yang berbeda lingkungan umur, budaya, status hidup dan tahap kecerdasan kognitif. Pelajaran bersistemkan kolaborarif dapat mengembangkan pembentukan pengetahuan, karakter dan skill setiap pelajar lebih efektif dan hasil kerja yang efisien. Hal ini demikian kerana kolaboratif menekankan proses kerja secara kumpulan berbanding perseorangan. Makanya, setiap pelajar yang tidak berkemampuan dalam kumpulan itu dipimpin oleh pelajar yang berkemampuan dalam kumpulan yang sama. Dengan cara ini, peratusan pelajar yang berkembang dalam kognitif, afektif dan psikomotorik lebih besar.

\section{Bentuk Pembelajaran yang Variasi}

Pembelajaran yang baik didukung melalui pelaksanaan pembelajaran yang baik. Setiap institusi atau gereja memerlukan paradigma pembelajaran yang variasi agar memupuk nilai pelajar yang bermutu baik dari segi pengetahuan, tingkah laku dan kemahiran. Terdapat empat bentuk pembelajaran yang mendorong meningkatkan prestasi Pembelajaran dan Pengajaran. Setiap bentuk

${ }^{28}$ www.maniyamin.blogspot.com

${ }^{29}$ Harianto GP, dkk., (2020), “CollaborativeCooperative Learning Model to Improve Theology Students' Characters: Is It Effective?" Cakrawala Pendidikan, 39 (2). Doi:10.21831/cp.v39i2.31272.

${ }^{30}$ Ibid.

Excelsis Deo: Jurnal Teologi, Misiologi, dan Pendidikan | 19 
pembelajaran memiliki kekuatan dan kelemahan yang tersendiri, maka harus diterapkan bentuk pembelajaran yang bersesuaian dengan keadaan dan keperluan dalam pendidikan pelajar. Bentuk-bentuk pembelejaran sebagai berikut:

Pertama, pembelajaran Behavioristik. Pembelajaran behavioristik atau pembelajaran tradisonal ini bersifat berpusat kepada pengajar. Bentuk pembelajaran ini menekankan bahawa pengajar sendiri membuat keputusan dan idea untuk membentuk pelajar atau anak murid dengan pengajaran - pengajaran yang difikirkannya. Walaupun terlihat seperti agak negatif atau bersifat diktator, namun bentuk pembelajaran ini mampu membentuk disiplin yang kuat dalam kalangan pelajar dan anak didik. Dalam pembelajaran bentuk ini, pelajar akan terus - menerus menunjukkan perubahan dari segi tingkah laku. Ada beberapa contoh perubahan yang berlaku sepertinya: (1) Perubahan yang terjadi secara sadar, (2) Perubahan dalam belajar bersifat berterusan dan efisien, (3) Perubahan dalam belajar bersifat positif dan aktif, (4) Perubahn dalam belajar tidak bersifat sementara, (5) Perubahan dalam belajar bertujuan, dan (6) Perubahan mencakup seluruh aspek dalam tingkap laku. ${ }^{31}$

Kedua, pembelajaran Konstruktivistik. Konstruktivistik merupakan himpunan dan pembinaan pengalaman demi pengalaman yang menyebabkan seseorang mempunyai pengetahuan dan lebih dinamis. ${ }^{32}$ Menghafal sesuatu fakta atau pelajaran mungkin menjadi kesukaran bagi pelajar yang lembam pemikirannya untuk menangkap ajaran yang diajarkan atau disampaikan, akan tetapi jika manusia mengajarnya untuk mengerti dan memahami sebuah pelajaran akan lebih senang baginya. Hal ini demikian kerana setiap perkembangan dan perjalanan kehidupan manusia akan pernah mengalami dan memiliki sebuah pengalaman dalam hidupnya yang mungkin besar boleh diterapkan sebagai pendukung pemahamannya. Dalam bentuk pembelajaran ini, pelajar atau anak didik yang bergerak

\footnotetext{
${ }^{31}$ Ibid.

${ }^{32}$ Ibid.
}

untuk memikirkan dan menyelesaikan masalah, bukan dari pengajar melalui cara tersendiri. Walaupun dalam bentuk ini agak seperti sebuah pengabaian pengajar terhadap seorang pelajar kerana pelajar ditekankan untuk berusaha untuk membangun pengetahuan melalui pengajaran yang disampaikan oleh para pengajar, namun pada akhirnya, dapat membina seorang pelajar yang mandiri dan berpengetahuan luas kerana dia dilatih untuk mengerahkan pemikiran yang meluas bukan bergantung kepada idea dan bantuan pengajar sahaja kerana seorang pelajar tersebut membina atau membangun pemahamannya sendiri terhadap masalah atau penemuannya dengan menggunakan pengalaman, cara berfikir dan keyakinan dirinya.

Hasil daripada bentuk Pembelajaran dan Pengajaran ini, pelajar tersebut bukan saja mengerti segala yang diajarkan, malah lebih yakin dengan pemahamannya terhadap pelajaran itu. Begitu juga dalam pengajaran kepada jemaah, mengajar sesuatu yang baru dengan menggunakan inti pengajaran di luar pengalaman atau kesaksian mereka agak sukar bagi pengajaran itu diterima dengan baik kerana ianya hanya akan menjadi sebuah hikayat, pengumuman atau informasi tambahan bagi mereka, bukan lagi menjadi hal yang mendorong dan membangun kerohanian mereka.

\section{Ketiga, Pembelajaran Kognitif.} Kognitif diertikan dengan proses penanggapan, pembinaan konsep, penaakulan, penilaian dan penyelesaian masalah dan teori kognitif didefiniskan sebagai gaya manusia yang menjadi pendorong dalam tindakannya berdasarkan cara berfikir mereka sendiri. Cara pembelajaran kognitif mengaitkan cara belajar dengan menekankan kepada perubahan proses mental dan pemahaman yang diterima serta sebagai "agen goal-directed yang aktif untuk mencari informasi. Proses pembelajaran ini terjadi jika pelajar tersebut mempunyai cukup pengalaman yang berkaitan dalam mempelajari pengalaman yang baru dan mahu terlibat sama dalam aktiviti pembelajaran. Berhasilnya pembelajaran ini jika terjadinya pengamatan, ingatan dan bayangan sepanjang pembelajarannya, di mana pengamatan 
melibatkan proses perhatian, ingatan merupakan proses pembinaan dan pengumpulan kembali pengalaman dan bayangan adalah suatu proses simulasi virtual dalam pemikiran. Langkah ini membawa individu mengubah sebuah kefahaman kepada bentuk kepahaman yang lain dan menyatakan idea dengan dasar kepahaman sendiri. Pembelajaran kognitif membawa pelajar untuk mengolah buah fikiran dan pemahamannya terhadap situasi yang berhubungan dengan tujuan belajarnya. ${ }^{33}$ Terdapat empat teori pembelajaran kognitif adalah: (1) Pelajar aktif dalam usaha untuk memahami pengalaman, (2) Pemahaman bahawa pelajar mengembangkan pemikiran bergantung kepada apa yang mereka ketahui, (3) Pembelajaran untuk membangun pemahaman dari catatan, dan

Pembelajaran merupakan perubahan dalam struktur mental individu.

Keempat, Pembelajaran Humanistik. Ada yang mencatatkan bahawa teori humanistic ini bertujuan untuk mentamadunkan manusia. Bentuk ini menjelaskan bahawa para pengajar membantu pelajar untuk mengembangkan dirinya dengan memahami dari sudut pandangnya sendiri bukan dari sudut pandang penemunya. Pembelajaran humanistik menjelaskan bahawa manusia bebas untuk menentukan arah hidupnya, di mana manusia bertanggungjawab penuh atas dirinya mahupun orang lain ${ }^{34}$ atau humanistic oriented. ${ }^{35}$ Maslow mengatakan manusia termotivasi untuk memenuhi keperluan keperluan hidupnya dan Carl Ransom Rogers menjelaskan perlunya sikap saling menghargai dan positif untuk mendorong individu menghadapi cabaran hidupnya. Pembelajaran ini menekankan kepentingan inti daripada proses pembelajaran yang bersifat elektif demi membawa manusia mencapai aktualisasi diri ${ }^{36}$ atau mengenal dan meningkatkan potensi diri. ${ }^{37}$

2013

${ }^{33}$ www.ainamulyana.blogspot.com

${ }^{34}$ Arbayah, Model Pembelajaran Humanistik,

${ }^{35}$ www.pondok-belajar.com

${ }^{36}$ Arbayah, Model Pembelajaran Humanistik,

2013

${ }^{37}$ www.pondok-belajar.com
Dari uraian tersebut dapat disimpukan bahwa kaedah-kaedah untuk meningkatkan kualitas pembelajaran dan pengajaran adalah dengan meningkatkan kualitas adalah: komunikasi pembelajaran dan pengajaran, kolaborasi, dan mengembangkan bentuk pembelajaran yang bervariasi.

\section{Meningkatkan Kualitas Pembelajaran dan Pengajaran melalui Model Kurikulum yang Efisien}

Kurikulum yang teratur dan terancang mampu memimpin proses Pembelajaran dan Pengajaran ke sebuah tahap pendidikan yang berkualiti dan bermutu tinggi. Hal ini demikian kerana kurikulum teratur bukan sahaja membawa seluruh Pembelajaran dan Pengajaran kepada visi dan misi sebuah institusi atau gereja, bahkan mampu memangkin dan meneguhkan serta melengkapi daya pengetahuan, tingkah laku dan kemahiran seorang individu tersebut baik dalam keluarga mahupun bagi masyarakat. Penetapan kurikulum harus dilakukan dengan teliti dan tepat agar berlaku keteraturan dan keseragaman penyampaian pelajaran, di samping memudahkan setiap pengajar mempersiap bahan ajar dan cara mengajar. Harianto GP mengatakan bahwa kurikulum tidak berhenti pada landasan teori, melainkan akan berhasil dan sangat bermanfaat bila ditanam, hidup, dan bertumbuh dalam berbagai praktik lapangan. Dengan demikian, diperlukan "kontekstualisasi" sebagai benang pengikat. Jadi agar teks dapat berdampak dalam perubahan hidup seseorang, teks (nilanilai Alkitab) perlu diletakan sebagai landasaran buku kurikulum. ${ }^{38}$

Terdapat empat cara untuk menghasilkan kurikulum yang efisien bagi pelaksanaan Pembelajaran dan Pengajaran dalam sebuah komuniti atau masyarakat.

\footnotetext{
${ }^{38}$ Harianto GP, Pendidikan Agama Kristen dalam Alkitab \& Dunia Pendidikan Masa Kini (Yogjakarta: Andi, 2012), 119.
}

Excelsis Deo: Jurnal Teologi, Misiologi, dan Pendidikan | 21 


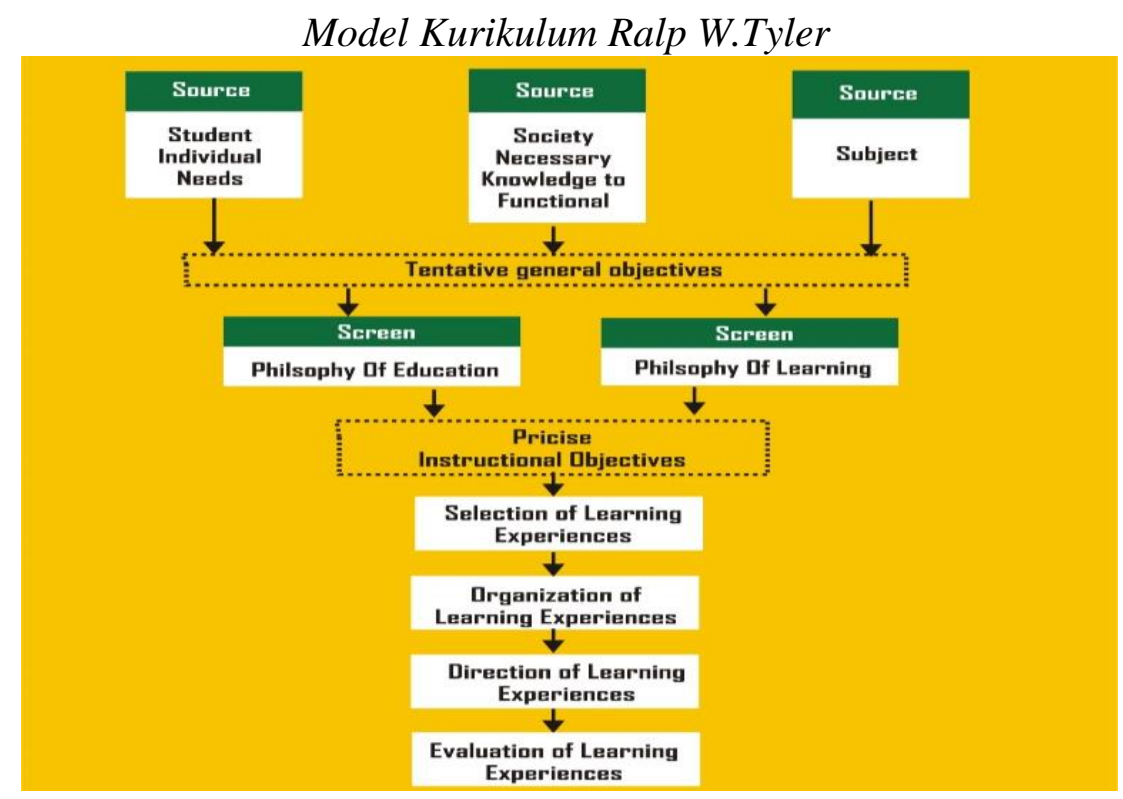

Tabel di atas merupakan model kurikulum yang diciptakan oleh Ralp W. Tyler. Model kurikulum ini dianggap sebagai model klasik, ${ }^{39}$ di mana Tyler menegaskan bahawa penggunaan objektif dalam mengembangkan kurikulum penting untuk mencapai tujuan pendidikan. Ada empat hal yang diperhatikan dalam model Tyler adalah: (1) Objektif pelajaran yang disampaikan harus selaras dengan keperluan pelajar dan masyarakat serta diperkira dengan aras kebolehan dan minat pelajar juga. ${ }^{40}$ (2) Kandungan. Isi pengajaran harus berdasarkan pemilihan dan perancangan pembelajaran pengajar, di mana ianya menuntut kreativiti pengajar itu sendiri dengan melibatkan prinsip kesinambungan, prinsip ketertiban dan prinsip kesepaduan. ${ }^{41}$ (3) Kaedah cara Pembelajaran dan Pengajaran dilakukan harus sesuai dengan kandungan pelajaran dengan mengambil kira bahan pelajaran untuk diajarkan kepada pelajar. (4) Penilaian. Prestasi Pembelajaran dan Pengajaran dapat dipastikan melalui sebuah hasil penilaian. Penilaian yang dilakukan secara berterusan atau melalui ujian akhir pelajar. ${ }^{42}$
Model Kurikulum Hilda Taba

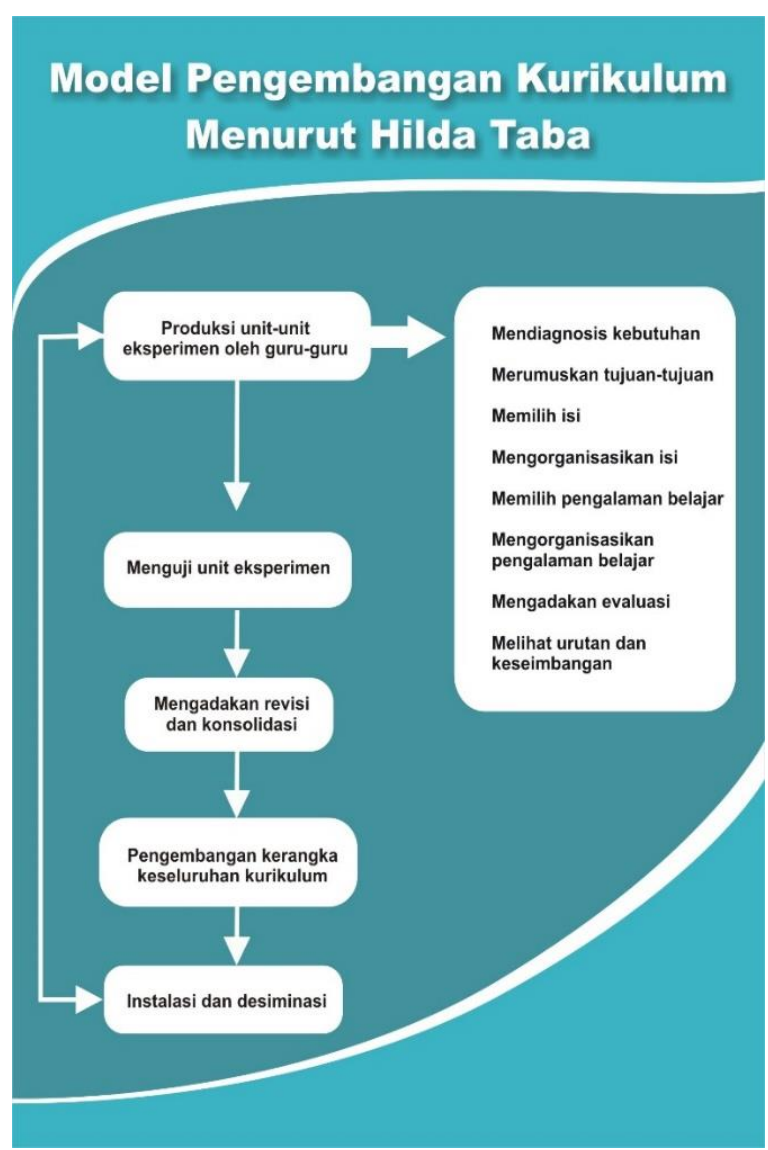

\footnotetext{
${ }^{39}$ www.academia.edu.com

${ }^{40}$ Ibid.

${ }^{41}$ Ibid.

${ }^{42}$ Ibid.
} 
Dalam model pengembangan kurikulum Taba, Hilda Taba menggalakkan untuk menggunakan pertimbangan terhadap isi kurikulum dan individu pelajar. ${ }^{43}$ Tambahan pula, pelaksanaan kurikulum bermula dengan mendiagnosis keperluan pelajar agar kurikulum selari dengan pengalaman pelajar kerana melibatkan kriteria dari pelbagai sumber seperti tradisi, tekanan sosial dan kebiasaan. Model kurikulum Taba menekankan cara untuk meneguhkan kecerdasan mental dan proses berfikir dengan menganalisis informasi dan konsep. ${ }^{44}$

\section{Model Kurikulum Peter Oliva}

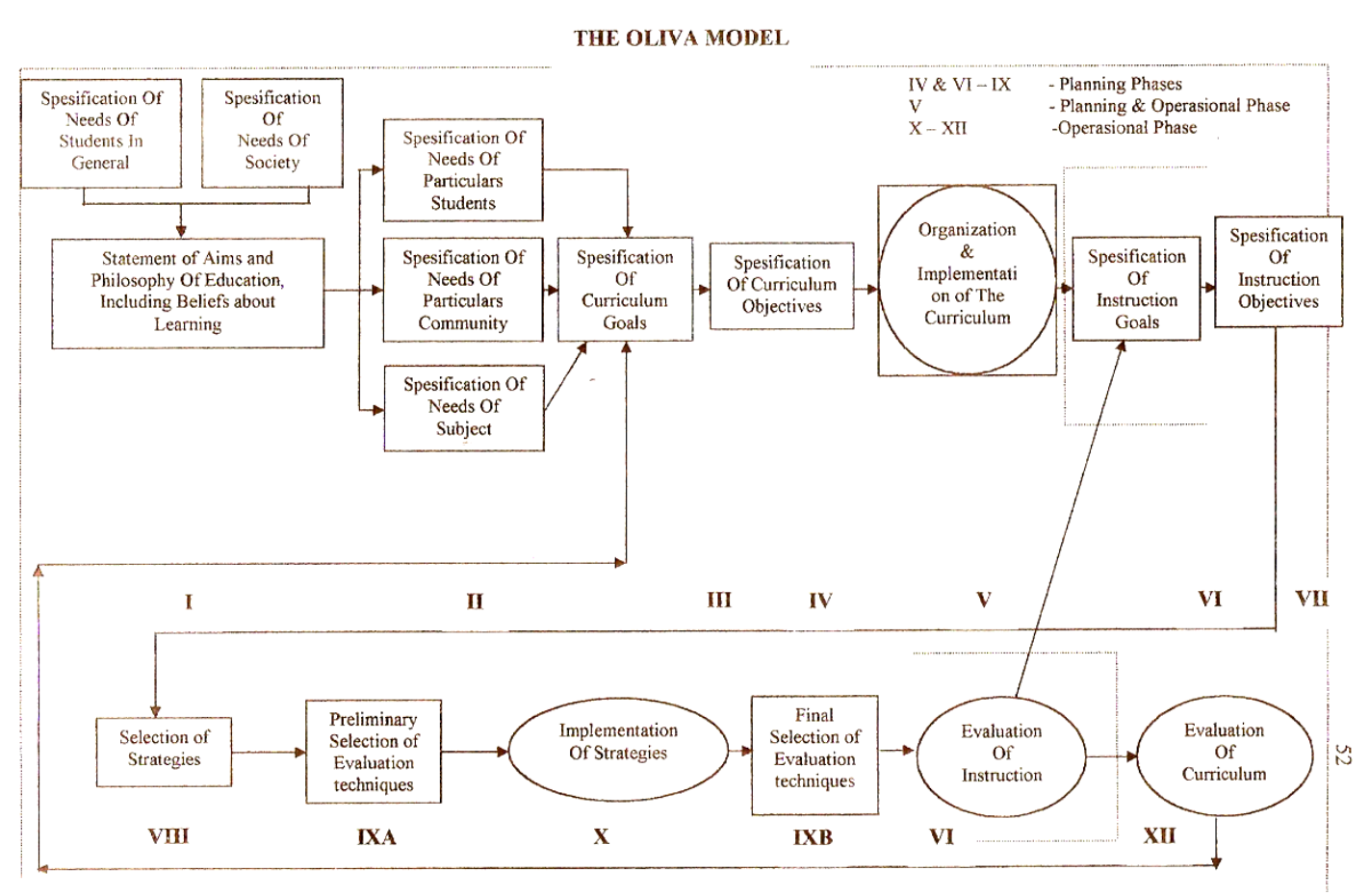

Model Kurikulum Oliva menjelaskan perancangan dalam perkembangan kurikulum yang terbahagi kepada tiga bahagian, iaitu sederhana, komprehensif dan sistematik. ${ }^{45}$ Model ini mengandungi 12 komponen adalah: (1) penentuan tujuan dari pendidikan dan landasan filosofi serta psikologi yang berasal dari keperluan individu dan masyarakat. (2) analisa daripada keperluan masyarakat dalam lingkungan institusi pendidikan itu berada. (3-4) sebagai tujuan khusus kurikulum berdasarkan tujuan. (5) membawa pengajar untuk menetapkan organisasi dan pengimplementasi kurikulum. (6-7) pelaksanaan lanjut yang mencakup tujuan instruksional umum dan khusus. (8) menjelaskan strategi pelaksanaan kurikulum, dan (9) penilaian kurikulum yang dilaksanakan.

\footnotetext{
${ }^{43}$ Www.psv3.blogspot.com

${ }^{44}$ www.academia.edu.com

${ }^{45} \underline{\text { www.kenniapril.blogspot.com }}$
} 


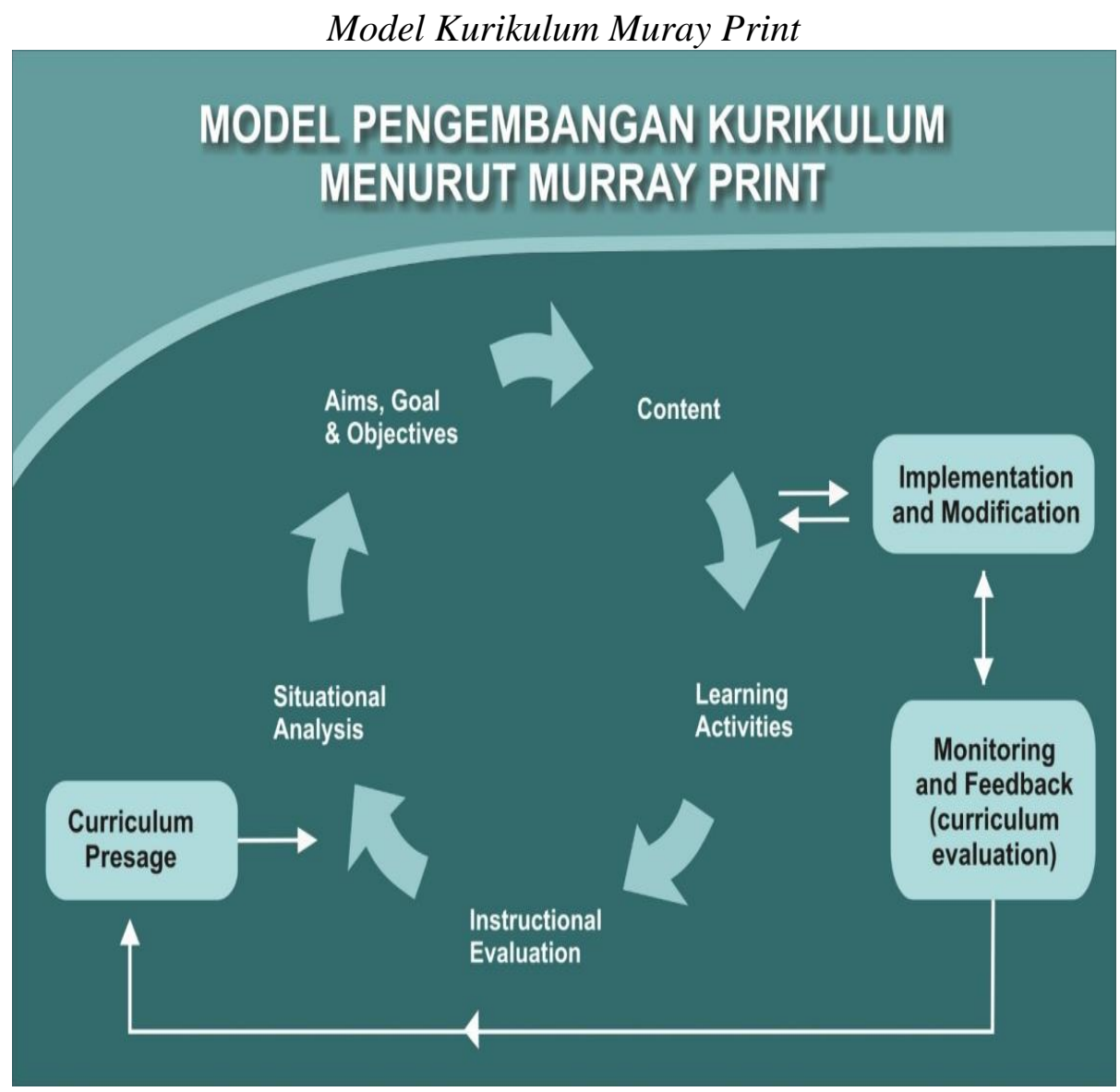

Muray Print menjelaskan bahwa kurikulum merupakan seluruh pengalaman belajar siswa yang ditawarkan oleh sekolah dan pengalaman tersebut diimplementasikan. ${ }^{46}$ Model Kurikulum Muray Print ini model bersifat berputar. Terdapat dua bentuk dasar dalam model adalah rasional dan dinamis. Model ini terlaksana dalam tiga tahap adalah: pengorganisasi, perkembangan dan aplikasi. ${ }^{47}$

\section{KESIMPULAN}

Dari kajian tersebut dapat disimpulkan sebagai berikut: Pertama, pengertian Pembelajaran dan Pengajaran merupakan suatu konsep yang berbeda meski menjadi proses perubahan dalam struktur belajar, yang melibatkan pengajar, pelajar, dan prasarana pendidikan. Kedua, kaedah-kaedah untuk meningkatkan kualitas pembelajaran dan pengajaran adalah dengan meningkatkan kualitas adalah: komunikasi pembelajaran dan

\footnotetext{
${ }^{46}$ Abidin, Concept of Curriculum
}

${ }^{47}$ Ibid.

24 | Vol. 2 No. 2 (Juli-Desember 2018) pengajaran, kolaborasi, dan mengembangkan bentuk pembelajaran yang bervariasi. Ketiga, meningkatkan kualitas pembelajaran dan pengajaran melalui model-model kurikulum yang efisien adalah: model kurikulum Ralp W.Tyler, model kurikulum Hilda Taba, model kurikulum Peter Oliva, atau model kurikulum Muray Print.

\section{Daftar Pustaka}

"Belajar." Wikipedia bahasa Indonesia, ensiklopedia bebas, November 19, 2020. Accessed November 24, 2020. https://id.wikipedia.org/w/index.php?ti tle=Belajar\&oldid $=17623207$.

"Peserta didik." Wikipedia bahasa Indonesia, ensiklopedia bebas, August 19, 2020. Accessed November 24, 2020. https://id.wikipedia.org/w/index.php?ti tle $=$ Peserta_didik\&oldid=17316371.

Arifin, Zainal. Evaluasi Pembelajaran: Teknik, Prinsip, dan Prosedur. Bandung: Remaja Rosdakarya, 2016. 
GP, Harianto, dkk. (2020), "CollaborativeCooperative Learning Model to Improve Theology Students' Characters: Is It Effective?" Cakrawala Pendidikan, 39 (2). Doi:10.21831/cp.v39i2.31272.

GP, Harianto. Komunikasi dalam Pemberitaan Injil. Yogjakarta: Andi, 2012.

GP, Harianto. Pendidikan Agama Kristen dalam Alkitab \& Dunia Pendidikan Masa Kini. Yogjakarta: Andi, 2012.

H.M., Jogiyanto. Analisis dan Disain Sistem Informasi. Yogjakarta: Andi, 1999.

https://www.quotes.net/quote/22671.

Lela, Noor, dkk. (2019), "Kepentingan Amalan Pengajaran dan Pembelajaran Abad 21 terhadap pembangunan pelajar", International Journal of Education, Psychology and Counseling, 4(28), 28-51.

McGehee, W. "Are We Using All We Know About Training? Learning Theory and Training," Personnel Psychology, (Spring 1958), 2.

Razali, Nuzaruan Bin. Tahap Prasarana Pendidikan Persekitaran Pembelajaran di Sekolah Menengah Daerah Kota Tinggi. Malaysia: Fakulti Pendidikan Universiti Teknologi Malaysia, 2013.

Robbins, Stephen P. Perilaku Organisasi Buku 1. Jakarta: Salemba Empat, 2007.

Saminanto. Ayo Praktik PTK (Penelitian Tindakan Kelas). Semarang: Rasail Media Group, 2010.

Slavin, Robert E. Educational Psychology: Theory and Practice. New Jersey: Pearson Education, 2000.

Trianto. Mendesain Model Pembelajaran Inovatif-Progresif. Jakarta: Kencana Prenada Media Group, 2011.

www.academia.edu.com

www.academia.edu.com

www.ainamulyana.blogspot.com

www.bobezani.tripod.com

www.cikguazni87.blogspot.com

www.intanrumapea.wordpress.com

www.iqteach.com

www.kenniapril.blogspot.com www.makna.online.com

www.maniyamin.blogspot.com

www.ms.m.wikipedia.org.com

www.pondok-belajar.com

www.pondok-belajar.com

www.prpm.dbp.gov.my.com

wWw.psv3.blogspot.com 
Excelsis Deo: Jurnal Teologi, Misiologi, dan Pendidikan 